\title{
Analisis Nilai Karakter Religius dan Nilai Karakter Tanggung Jawab Pada Tembang Dolanan Lir-ilir dan Sluku-Sluku Bathok
}

\author{
Tyas Puspita Dewi| Purwadi | Mudzanatun \\ PGSD FIP Universitas PGRI Semarang \\ Jalan Sidodadi Timur No 24.
}

\begin{abstract}
Abstrak
Negara Indonesia adalah bangsa yang mempunyai berbagai macam seni budaya. Arus modernisasi membawa kemajuan dalam berbagai hal dan tak jarang pula membawa dampak negatif bagi identitas dan jati diri suatu bangsa jika kita tidak bisa menyikapinya dengan baik. Salah satu cara untuk memperbaiki penurunan kualitas karakter adalah dengan mengenalkan kembali budaya-budaya bangsa. Tembang dolanan anak Jawa merupakan salah satu sarana budaya yang mampu mengubah karakter generasi penerus bangsa Indonesia. Jenis penelitian ini adalah kualitatif deskriptif dengan mencari dan menggambarkan nilai pendidikan karakter religius dan tanggung jawab yang terdapat dalam lirik tembang dolanan Lir-ilir dan Sluku-sluku Bathok. Data yang dikumpulkan melalui kajian wawancara, observasi, dan dokumentasi, dari narasumber dan teks bacaan. Nilai karakter yang terdapat pada tembang dolanan Jawa dapat dijadikan sarana bagi tenaga kependidikan ataupun masyarakat dalam menanamkan pendidikan karakter sejak usia dini. Selain sebagai sarana menanamkan pendidikan karakter, kita juga dapat ikut berpartisipasi dalam melestarikan kebudayaan leluhur.
\end{abstract}

Kata Kunci : Nilai karakter, religius, tanggung jawab, tembang dolanan.

\section{Pendahuluan}

Negara Indonesia adalah bangsa yang mempunyai berbagai macam seni budaya. Beragam jenis seni budaya yang ada dan berkembang dalam masyarakat, menggambarkan betapa kayannya seni budaya yang ada di negara Indonesia ini. Ragam seni budaya tersebut meliputi kebudayaan asli Indonesia yang tersebar di seluruh daerah-daerah di wilayah Indonesia dan masih bersifat tradisional (Yuliantoro, 2014:1).

Sekarang ini kita telah masuk dalam arus moderenisasi, di mana kita dihadapkan dengan masuknya berbagai kemajuan di berbagai bidang, seperti politik, ekonomi, iptek dan sosial budaya. Arus modernisai banyak membawa kemajuan di berbagai hal, namun perlu diperhatikan bahwa arus modernisasi juga dapat menggerus idetitas dan jati diri bangsa jika kita tidak bisa menyikapinya dengan baik. Penanaman nilai-nilai budi pekerti pada anak merupakan modal penting dalam menghadapi dampak negatif dari kemajuan teknologi (Yuliantoro, 2014:1).

Pembentukan karakter anak sesugguhnya sudah tercantum dalam tujuan pendidikan. Seperti yang ditegaskan dalam undang-undang sistem pendidikan nasional No.20 tahun 2003 pasal 3 yang menjelaskan bahwa pendidikan bertujuan untuk berkembangnya potensi peserta didik agar manusia yang beriman dan bertawa kepada Tuhan Yang Maha Esa, berakhlak mulia, sehat, berilmu, cakap, kreatif, mandiri dan menjadi warga negara yang demokratis serta bertanggung jawab.

*Penulis Korespondensi. Email: tyaspuspita342@gmail.com 
Oleh karena itu, pendidikan di ciptakan tidak hanya bertujuan untuk memberi ilmu pengetahuan kepada peserta didik tetapi juga bertujuan untuk mengembangkan kreatifitas dan membina sikap kepribadian pada diri seseorang, sehingga akan seimbang antara ilmu pengetahuan dan jiwa yang berkarakter. Menurut Rahman dalam (Amri, 2012:2) menilai bahwa sampai saat ini masih ada yang keliru dalam pendidikan di tanah Air. Menurutnya pendidikan di negara Indonesia lebih menitikberatkan pada kemampuan kognitif. Penentu kelulusan masih lebih banyak pada prestasi akademik dan kurang memperhitungkan akhlak dan budi pekerti yang baik. Dapat dikatakan bahwa penyebab terbesar dalam krisis pendidikan ini adalah gagalnya pembangunan karakter anak didik. Kegagalan ini terjadi karena aspek akhlak atau moralitas terabaikan dalam proses pendidikan yang sedang berlangsung.

Menurut (Amri, 2012:8) ada 2 aspek yang kurang mendapat perhatian dari pemerhati pendidikan, yaitu aspek agama dan aspek budaya. Padahal kedua aspek tersebut sangat penting untuk digali dan diteliti karena sangat berpengaruh dalam menentukan hasil didikan karakter seorang peserta didik. Karakter seorang manusia sangat erat kaitanya dengan agama, lingkungan, dan budaya di mana ia tinggal dan dibesarkan. Pendidikan karakter juga dapat diselipkan melalui berbagai kesenian tradisional salah satunya melalui tembang dolanan. Tembang dolanan terdapat pada mata pelajaran muatan lokal (mulok) pada pendidikan dasar yang telah berlaku sejak 1994. Tujuan program tersebut adalah memberikan pendidikan apresiasi seni kepada siswa sekolah dasar, agar seni tradisional tidak hilang dari budaya jawa. Kurikulum Mulok disusun untuk mewujudkan pelestarian dan pengembangan serta memberikan keterampilan berkesenian bagi peserta didik sebagai pewaris kebudayan nenek moyang mereka. Pembelajaran bahasa Jawa merupakan salah satu mata pelajaran muatan lokal yang di dalamnya mengandung nilai kearifan lokal dan nilai-nilai budi pekerti. Pembelajaran tembang dolanan seharusnya disampaikan secara totalitas karena di dalam materi ini mengandung banyak nilai-nilai luhur warisan nenek moyang yang mampu menyampaikan makna yang tersirat dalam tiap-tiap syair atau lirik.

Setelah melakukan wawancara dengan Ibu Rika guru pengampu pelajaran muatan lokal bahasa Jawa, di dalam penyampaian materi tembang dolanan beliau menyampaikan dengan cara bercerita ataupun melalui bentuk permainan kemudian dilanjutkan dengan menyanyikan tembang dolanan secara bersama-sama. Beliau merupakan salah satu lulusan Universitas Negeri Semarang dan sudah menjadi tenaga pendidik sejak tahun 1967 hingga sekarang. Pada saat mewawancarai Ibu Maryani, salah satu tenaga pendidik di SDN Tlogosari Kulon 04 Semarang beliau mengajarkan tembang dolanan dengan cara menyanyikan tembang dolanan serta mengajak siswa untuk menari. Menurut (Yuliantoro, 2014:2) pada saat mengajarkan materi tembang dolanan, guru dapat memanfaatkan bentuk permainan diiringi menyanyikan tembang dolanan untuk menarik minat anak. Yang perlu di tekankan adalah konteks budi pekerti dan kebangsaan yang harus diimplikasikan dalam tiap lirik tembang dolanan. Proses sosialisasi dan implementasi dilakukan di dalam kelas. Setelah melatih bernyanyi dan diselingi permainan, guru harus menjelaskan arti tiap kata dan simbol bahasa sesuai tingkat usia anak. Selanjutnya diberikan penjelasan relevansinya dengan wujud kebangsaan yang muncul pada tiap unsur-unsur lirik lagu. Dengan cara-cara demikian di rasa cukup menarik perhatian siswa dalam mempelajari tembang dolanan.

Menentukan materi pendidikan tembang (lagu) dolanan anak-anak khususnya di sekolah taman kanakkanak dan sekolah dasar yang sesuai dengan perkembangan usia anak tidak mudah, hal ini karena pengaruh perkembangan teknologi informasi dengan mudah dan cepat dinikamti dan didapatkan dilingkungan rumah (keluarga) maupun di masyarakat setiap saat. Bahkan di dalam kendaraan umumpun mendapatkan pelayanan audio visual secara gratis dan menghibur dengan lagu-lagu percintaan. Namun, pada bahasan mengenai tembang (lagu) dolanan anak-anak sebagai pokok bahasan hendaknya dapat dimasukan materi muatan lokal guna tercapainya tujuan pembelajaran (Muljono, 2012:101).

Menurut Ki Hadjar Dewantoro dalam (Muljono, 2012:3), Pada bukunya yang berjudul sari swara mengatakan : bahwa pelajaran tembang (sekar) atau gending Jawa itu amat besar memberikan kekuatan dalam membentuk budi pekerti yang halus, memantapkan rasa kebangsaan serta menguasai dalam belajar sastra. 
Berdasarkan observasi di SDN Tlogosari Kulon 04 Semarang penulis menemukan masalah bahwa masih banyak siswa yang kurang hafal dengan lirik tembang dolanan Lir-ilir. Hal tersebut di buktikan di saat guru kelas meminta seluruh siswa kelas 6 menyanyikan beberapa tembang dolanan, di saat mereka menyanyikan tembang dolanan Lir-ilir, sebagian dari mereka ada yang kurang hafal dengan lirik lagu tersebut. Hal tersebut menjadikan peneliti ingin mengkaji nilai karakter yang terdapat pada beberapa tembang dolanan seperti tembang dolanan Lir-ilir dan Sluku-sluku Bathok. Dengan harapan dapat memperkenalkan kembali tembang dolanan kepada siswa SDN Tlogosari Kulon 04 dan para pembaca. Berdasarkan buku yang disusun oleh Badan Pengembangan Pusat Kurikulum Kemendiknas RI ada 18 karakter pendidikan budaya bangsa. Namun pada penelitian ini, penulis hanya memfokuskan 2 nilai karakter yaitu nilai karakter religius dan nilai karakter tanggung jawab.

Menurut UU Nomor 35 Tahun 2014 tentang perlindungan anak Pasal 6 disebutkan bahwa setiap anak berhak beribadah menurut agamanya, berpikir, dan berekspresi sesuai dengan tingkat kecerdasan dan usianya dalam bimbingan orang tua atau wali. Hal ini berarti peran orang tua sangat diperlukan saat memilih lagu-lagu anak yang sesuai dengan tingkat usianya. Tembang dolanan yang sesuai dengan kognitif dan usia anak di jenjang sekolah dasar antara lain Sluku-sluku Batok yang terdapat pada buku seneng basa kelas 2 penerbit CV. Tri Rama Solo dan tembang Lir-ilir pada buku seneng basa kelas 6 penerbit CV.Tri Rama Solo. Tembang dolanan melalui pengajaran serta penerapan simbol dan makna melalui lirik dan maknanya akan sangat membantu guru dalam memberikan materi sastra dan seni. Di sisi lain siswa akan tertarik sebab pembentukan karakter yang baik dituntun melalui proses belajar antara seni, sastra, dan moral. Dengan demikian, siswa diharapkan memiliki jiwa-jiwa berkarakter yang berpondasi agama dan etika kuat tanpa meningalkan nilai-nilai luhur budaya (Muljono, 2010: 5). Menurut (Winarti, 2010:1) kajian-kajian tentang tembang dolanan masih jarang dilakukan. Tidak terlihat adanya perhatian yang cukup besar dari kalangan ilmuwan terhadap fenomena budaya ini, kecuali dari kalangan tertentu. Pada umumnya tembang dolanan banyak dikaji sebagai bagian dari kajian tentang permainan anak (Mangoenprawira, 1941; Yunus, 1980/1981; Dept. P dan K Proyek Investarisasi dan Dokumentasi Kebudayaan Daerah, 1981/82; dan Dharmamulya dkk, 2008). Kajian lagu dolanan yang cukup lengkap ditulis oleh Overback (1935). Kajian-kajian seperti di atas jelas memberikan manfaat bagi setiap upaya pelestarian tembang dolanan. Untuk itu, penulis ingin mencoba mengambil bagian dalam melanjutkan berbagai kajian yang telah dilakukan terhadap tembang dolanan, yang tentunya dengan pendekatan berbeda, yaitu dengan menganalisis nilai karakter pada tembang dolanan.

\section{Metode Pelaksanaan}

Jenis penelitian yang digunakan adalah penelitian kualitatif. Prosedur pengumpulan datanya menggunakan teknik wawancara. Cara yang dilakukan yaitu wawancara tersetruktur dengan cara peneliti memberikan teks pedoman wawancara kepada narasumber kemudian merekam dan mencatat informasi penting yang diberikan oleh narasumber. Metode simak dan catat bagi penulis merasa sangat membantu dalam memproses data, dalam hal ini untuk menganalisis nilai karakter yang terdapat pada teks tembang dolanan Lir-ilir dan Sluku-sluku Bathok dalam buku Seneng Basa. Peneliti terlibat langsung dalam menganalisis dan menyimak setiap kata dan kalimat, kemudian hasilnya akan di catat dalam kartu data. Nilai karakter yang muncul adalah cerminan arti atau maksud terjemahan lirik tembang dan dokumentasi penelitian ini menggunakan dokumen berupa buku paket Seneng Basa untuk siswa kelas II dan VI Penerbit CV. Tri Rama Solo, teks tembang dolanan Lir-ilir dan Sluku-sluku Bathok yang ada pada buku Seneng Basa yang merupakan objek penelitian beserta foto yang merupakan bukti bahwa peneliti telah melakukan observasi maupun wawancara dengan narasumber.

\section{Hasil dan Pembahasan}

Dalam satu kali produksi menghasilkan 25 bungkus permen jeli daun kelor, dengan masing-masing Temuan hasil penelitian berupa tabel nilai karakter tembang dolanan, rangkuman kartu data yang berisi 
syair tembang dolanan Lir-ilir dan Sluku-sluku Bathok beserta terjemahan dan nilai karakter yang terkandung di dalamnya.

Tabel 1. Analisis Nilai Karakter yang Terdapat dalam Tembang Dolanan.

\begin{tabular}{|c|c|c|c|}
\hline \multicolumn{4}{|c|}{ KARTU DATA NILAI KARAKTER DALAM LIRIK TEMBANG DOLANAN } \\
\hline \multicolumn{4}{|c|}{ Nama tembang : Lir-ilir } \\
\hline Lirik ke & Lirik Lagu & Terjemahan & Nilai Karakter \\
\hline 1 & Lir-ilir tandure wis sumilir & $\begin{array}{l}\text { Bangun, bangun tanaman yang di } \\
\text { tanam sudah tumbuh. }\end{array}$ & $\begin{array}{l}\text { Religius } \\
\text { Tanggung Jawab }\end{array}$ \\
\hline 2 & $\begin{array}{l}\text { Tak ijo royo-royo, tak } \\
\text { sengguh penganten anyar. }\end{array}$ & $\begin{array}{l}\text { Warnanya tanaman menghijau, } \\
\text { kusangka seperti, pengantin baru. }\end{array}$ & $\begin{array}{l}\text { Religius } \\
\text { Tanggung Jawab }\end{array}$ \\
\hline 3 & $\begin{array}{l}\text { Bocah angon peneken } \\
\text { blimbing kuwi. }\end{array}$ & $\begin{array}{l}\text { Anak gembala, panjatkanlah } \\
\text { belimbing itu. }\end{array}$ & $\begin{array}{l}\text { Religius } \\
\text { Tanggung Jawab }\end{array}$ \\
\hline 4 & $\begin{array}{l}\text { Lunyu-lunyu peneken,kanggo } \\
\text { masuh dododira. }\end{array}$ & $\begin{array}{l}\text { Walaupun licin usahakan panjatlah, } \\
\text { untuk mencuci kain dodotmu. }\end{array}$ & $\begin{array}{l}\text { Religus } \\
\text { Tanggung Jawab }\end{array}$ \\
\hline 5 & $\begin{array}{l}\text { Dododira k'mitir bedhah ing } \\
\text { pinggir. }\end{array}$ & $\begin{array}{l}\text { Pakainmu terkoyak di bagian } \\
\text { pinggir. }\end{array}$ & Religius \\
\hline 6 & $\begin{array}{l}\text { Domana jlu matana, kanggo } \\
\text { seba mengko sore. }\end{array}$ & $\begin{array}{l}\text { Jahitlah, perbaikilah untuk } \\
\text { menghadap nanti sore. }\end{array}$ & $\begin{array}{l}\text { Religius } \\
\text { Tanggung Jawab }\end{array}$ \\
\hline 7 & $\begin{array}{l}\text { Mumpung gedhe rembulane. } \\
\text { Mumpung jembar kalangane. }\end{array}$ & $\begin{array}{l}\text { Senyampang bulan bersinar terang, } \\
\text { kebetulan tak ada kabut yang } \\
\text { menghalangi. }\end{array}$ & $\begin{array}{l}\text { Religius } \\
\text { Tanggung Jawab }\end{array}$ \\
\hline 8 & Ya surak-a, surak hore. & $\begin{array}{l}\text { Ayo bersorak, bersorak hore } \\
\text { (dengan gembira). }\end{array}$ & Religius \\
\hline
\end{tabular}

Syair tembang dolanan yang berjudul 'ilir-ilir'" mengandung nilai karakter religius dan tanggung jawab. Tembang tersebut menceritakan pesan bahwa sebagai umat manusia diminta untuk bangkit (bangun) dari keterpurukan, dengan mempertebal iman dan takwa berjuang menjalankan syariat beragama yang di ibaratkan dengan peneken blimbing kuwi. Meskipun dalam pelaksanaanya sulit harus di kerjakan, sebagai bentuk tanggung jawab insan manusia terhadap sang pencipta.

Tabel 2. Analisis Nilai Karakter yang Terdapat dalam Tembang Dolanan.

KARTU DATA NILAI KARAKTER DALAM LIRIK TEMBANG DOLANAN

Nama tembang : Sluku-sluku Bathok

\begin{tabular}{crrr}
\hline Lirik ke & Lirik Lagu & Terjemahan & Nilai Karakter \\
& & & \\
\hline 1 & Sluku-sluku bathok & Ayun-ayun kepala & Tanggung jawab
\end{tabular}




\begin{tabular}{|c|c|c|c|}
\hline & & & Religius \\
\hline 2 & Bathoke ela-elo & Kepalanya geleng geleng & Religius \\
\hline \multirow[t]{2}{*}{3} & Si Rama menyang Sala & Si Ayah pergi ke Sala & Religius \\
\hline & & & Tanggung Jawab \\
\hline 4 & Oleh-oleh payung motha & $\begin{array}{l}\text { Oleh-olehnya payung mutho } \\
\text { (payung kematian) }\end{array}$ & Religius \\
\hline \multirow[t]{2}{*}{5} & Mak jenthit lo lo lo bah & Bergerak secara tiba-tiba. & Religius \\
\hline & & & Tanggung Jawab \\
\hline 6 & Wong mati ora obah & Orang mati tidak bergerak. & Religius \\
\hline \multirow[t]{2}{*}{7} & Yen obah medeni bocah & Kalau bergerak menakuti anak- & Religius \\
\hline & & & Tanggung Jawab \\
\hline 8 & Yen urip goleka duwit & Kalau hidup carilah uang. & Tangung Jawab \\
\hline
\end{tabular}

Tembang 'Sluku-sluku Bathok'" mengajarkan kepada kita nilai-nilai untuk cinta kepada Tuhan dan memiliki rasa tanggung jawab terhadap kehidupan yang dijalani. Makna yang termuat dalan lirik lagu tersebut bahwa hidup tidak boleh dihabiskan hanya untuk bekerja. Jiwa raga harus dikondisikan dengan seimbang. Untuk itu diperlukanlah istirahat salah satu caranya yaitu melalui dzikir serta mengingat Asma Allah dengan menggeleng-gelengkan kepala (ela-elo) dengan mengucap Laa illa ha ilallah. Hal tersebut hendaknya dilakukan dalam berbagai kondisi, baik ketika sedih, ketika senang, ketika mendapatkan kenikmatan, maupun musibah. Semuanya dilakukan atas tanggung jawab dan kesadaran bahwa hidup dan mati semua ada di tangan Tuhan. Ketika masih diberikan kesempatan untuk hidup hendaknya rajin beribadah, rajin bekerja atas dasar ridha Allah. Karena apabila sewaktu-waktu dipanggil untuk menghadap-Nya, kita tidak mampu melakukan apa pun lagi.

\section{Kesimpulan}

Berdasarkan hasil penelitian dalam deskripsi data dan pembahasan yang telah diuraikan oleh peneliti, maka dapat ditarik kesimpulan bahwa pada pada tembang dolanan Lir-ilir dan Sluku-sluku Bathok, banyak mengandung nilai karakter religius dan tanggung jawab yang baik bagi pembentukan karakter anak. Melalui pembelajaran tembang dolanan dan maknanya dapat diketahui bahwa banyak sekali pesan moral yang terdapat dalam tiap lirik lagu yang berguna bagi pembentukan karakter anak untuk memiliki sikap dan kepribadian religius. Melalui pembelajaran Bahasa Jawa dengan materi tembang dolanan Jawa diharapkan dapat dijadikan sebagai usaha dalam pelestarian budaya tradisional Jawa. Melalui bimbingan gurunya dalam pembelajaran Bahasa Jawa anak-anak dapat mengapresiasi tembang dolanan Jawa yang sarat akan nilai-nilai luhur sebagai pembentuk karakternya.

\section{Referensi}

Amri, Ulil. 2012. Pendidikan Karakter Berbasis Al Qur'an. Jakarta: PT Raja Grafimdo. 
Arikunto, Suharsimi. 2010. Prosedur Penelitian Suatu Pendekatan Teori dan Praktik. Jakarta : PT. Rineka Cipta. Berbahasa Jawa: Analisis Fungsi. Jurnal Ilmiah Kebahasaan dan Kesastraan. (Cetak). Vol 38 , ISSN 0215-9171, 12 halaman.

Fadli, Failasuf, dan Hasan Susanto. 2017. Model Pendidikan Islam Kreatif Walisongo, Melalui Penyelenggaraan Pendidikan Yang Menyenagkan. Jurnal Kebudayaan Islam. (Online). Vol 11 No 1. Tersedia : https://scholar.google.co.id/scholar?hl=id\&q=model+pendidikan+islam+kreatif+walisongo+ melalui+penyelengarran+pendidikan+yang+menyenangkan\&btnG= (20 Juli 2017).

Farida. 2012. Reaktualisasi Tembang Dolanan Jawa Dalam Rangka Pembentukan Karakter Bangsa (Kajian Semiotik). Kajian Linguistik dan Sastra. (Online). Vol24No1.Tersedia:https://scholar.google.co.id/scholar?q=reaktualisasi+te Daryanto. 2013. Pendidikan Karakter "' (studi komparatif pemikiran Ki Hajar Dewantara dan Azyumardi Azra). Jurnal Pendidikan Karakter (online). Vol 13 No 1. Tersedia : http://eprints.unipdu.ac.id/117/ (30 Maret 2017).

Depdiknas, 2012. Undang-undang Republik Indonesia Nomor 14 tahun 2005 Tentang Guru dan Dosen. Bandung : Citra Umbara.

Dwijawiyata. 2007. Tembang Dolanan. Yogyakarta: Kanisius.

Fadli, Failasuf, dan Hasan Susanto. 2017. Model Pendidikan Islam Kreatif Walisongo, Melalui Penyelenggaraan Pendidikan Yang Menyenagkan. Jurnal Kebudayaan Islam. (Online). Vol 11 No 1. Tersedia : https://scholar.google.co.id/scholar?hl=id\&q=model+pendidikan+islam+kreatif+walisongo+ melalui+penyelengarran+pendidikan+yang+menyenangkan\&btnG $=(20 \mathrm{Juli} 2017)$.

Farida. 2012. Reaktualisasi Tembang Dolanan Jawa Dalam Rangka Pembentukan Karakter Bangsa (Kajian Semiotik). Kajian Linguistik dan Sastra. (0nline). Vol 24 No 1. Tersedia : https://scholar.google.co.id/scholar?q=reaktualisasi+tembang+dolanan\&btnG=\&hl=id\&as_sdt $=0 \% 2 \mathrm{C} 5$ (13 Maret 2017).

Herawati, Nanik. 2009. Kesenian Tradisional Jawa. Klaten.: PT Macanan Jaya Cemerlang.

http://www.sastra.org/leksikon (diakses 30 Juli 2017)

Jabrohim. 1994. Teori Penelitian Sastra. Yogyakarta: IKIP Muhamadiyah Yogyakarta.

Kadijo, dkk. 2005. Seneng Basa. Solo: CV.Tri Rama Solo.

Kaelan. 2010. Pendidikan Pancasila. Yogyakarta : Paradigma.

Kesuma, Dharma, dkk. 2012. Pendidikan Karakter Kajian Teori dan Praktik di Sekolah. Bandung: PT.Remaja Rosdakarya.

Majid, Abdul, dan Dian Andayani 2012. Pendidikan Karakter Perspekif Islam. Bandung: PT.Remaja Rosdakarya.

Moleong, Lexy, J. 2010. Metodologi Penelitian Kualitatif. Bandung: PT Remaja Rosdakarya.

Muljono, Untung. Pendidikan Nilai Luhur Melalui Tembang(Lagu) Dolanan Anak. Jurnal Selonding. Jurnal Etnomusikologi Indonesia. (Online). Vol 1 No 1. Tersedia : http://journal.isi.ac.id/index.php/selonding/article/view/67 (4 April 2017).

Nurgiyantoro, Burhan. 2005. Sastra Anak. Yogyakarta: Gadjah Mada University Press. 